\title{
ANALYZE FACTORS THAT AFFECT ENTREPRENEURS OF MICRO, SMALL, MEDIUM ENTERPRISES INTENTION TO USE ACCOUNTING INFORMATION SYSTEMS BASED ON FLOW THEORY
}

\author{
I Nyoman Agus Wijaya ${ }^{1}$ Ita Salsalina Lingga ${ }^{2}$ Debbianita $^{3}$ Maria $^{4}$ \\ 1234 Universitas Kristen Maranatha, Bandung-Indonesia \\ aguswijaya.inyoman@gmail.com
}

\begin{tabular}{|c|c|}
\hline INFO ARTIKEL & ABSTRAK/ABSTRACT \\
\hline $\begin{array}{l}\text { Histori Artikel : } \\
\text { Tgl. Masuk : 07-01-2021 } \\
\text { Tgl. Diterima : 20-03-2021 } \\
\text { Tersedia Online : 31-03-2021 } \\
\text { Keywords: } \\
\text { theory of flow, behavioral intention to } \\
\text { use, accounting information systems, } \\
\text { actual usage. }\end{array}$ & $\begin{array}{l}\text { This study aims to analyze factors that affect } \\
\text { entrepreneurs of micro, small and medium enterprises } \\
\text { (MSME) intention to use accounting information systems } \\
\text { (AIS). This research model is based on theory of flow } \\
\text { which analyzes attitude towards AIS Use, Perceived } \\
\text { Enjoyment and Concentration as factors that affect } \\
\text { behavioral intention to use and its impact to actual usage. } \\
\text { Analysis of data uses Partial Least Square (PLS) of } \\
\text { Structural Equation Modeling (SEM). Unit of analysis in } \\
\text { this research are entrepreneurs of Micro, Small, and } \\
\text { Medium Enterprises (MSME) in Bandung City. In order to } \\
\text { obtain primary data, we use questionnaires. The result of } \\
\text { this research is intended to solve the problem of low } \\
\text { intention to use AIS which gives impact to AIS usage. }\end{array}$ \\
\hline
\end{tabular}

\section{INTRODUCTION}

The role of Micro, Small, and Medium Enterprises (MSME) in IndoneAIS is very important for economic development. Based on data from the World Economic Forum (2013), IndoneAIS shows a competitiveness ranking at number 5 out of 10 countries in ASEAN and in ASEAN, more than $96 \%$ of companies are MSME. According to BPS data (2012), the contribution of MSME to Indonesia's Gross Domestic Product (GDP) reached IDR 4,865.5 T (59.08\%) and employment reached $\quad 107,657,509 \quad(97.16 \%)$. Therefore, the government continues to empower MSME so that they can develop and have competitiveness, MSME is one of the sectors that have been able to sustain their business after the posteconomic crisis sectors and is becoming the driving force of the economy as well as absorbing large work vacancies. The government through the Ministry of Cooperatives and MSME has collaborated with the local governments to build cooperatives and MSME in IndoneAIS as a business (industrial) strategy in developing the growth of the national economy so that this strategic business (industry) has superior competitiveness and can compete with large industries. both in their home country and abroad.

Although the role of MSME is very important in improving the national economy, there are still several obstacles (both internal and external) that hinder the growth of MSME in IndoneAIS that must be addressed immediately. For example, MSME is still deemed not optimal in developing production, producing innovative products that are able to compete in the market, as well as the lack of the ability of Human Resources (HR) to master and utilize information technology 
to optimal use of capital. Limited working capital, low human resource competence, and minimal mastery of science and technology are the biggest obstacles for MSME in facing global competition, many MSME owners also do not understand the importance of Information and Communication Technology.

In terms of procurement of goods and services, the government uses information technology assistance, but many entrepreneurs who still do not get the understanding, are less able to utilize it, and also still use traditional systems because of the lack of knowledge about how to develop their business, especially in terms of procuring government goods and services. There are 7 principles of government procurement of goods and services, namely: be efficient, be effective, be transparent, be open, be competitive, be fair / non-discriminatory, and be accountable. The use of ICT needed to fulfill these principles is implemented in an effort to increase accountability and transparency, increase the market size and business and product competition, increase the procurement process efficiency, improve the processes and inspections, and increase the ability to obtain access to real-time information.

One of the efforts to increase the competence of MSME business players regarding information technology is the collaboration carried out by the University of North Sumatra (USU) with PT Telkom, they initiated a program to develop MSME in North Sumatra, one of which is called a digital village, they utilize information technology in a massive and comprehensive and integrative way in order to improve business development that runs in the MSME or MSME sector which is centralized in a particular location in an effort to create millions of advanced, independent and modern MSME. By getting to know digital and doing digital marketing, his party hopes that MSME players assisted by CIKAL USU can enter the retail market (Ritha Dalimunthe, 2016).

In addition, MSME also faces trade liberalization problems, such as the implementation of the ASEAN-China Free
Trade Area (ACFTA) which was willing to be effective in 2010. Likewise, the implementation of the ASEAN Economic Community (AEC) which came into effect in 2016 which caused high competition. Therefore, the government should make efforts to protect MSME as a support for the national economy, so that MSME can become a buffer for the national economy.

This research is also supported by the results of research previously carried out by Budiarto et al. (2015) in the concept of literature which explains the factors that influence the application of accounting information systems to MSME and their impact on the financial performance. Jogiyanto (2007) stated that technology acceptance models include the Technology Acceptance Model (TAM), Theory of Planned Behavior, and Theory of Flow. Which is one of the most influential and commonly used theories of information technology system application in explaining individual acceptance of the use of information technology systems.

Role of MSME in Indonesia is very important in improving the national economy, but there are still several obstacles (both internal and external) that hinder the growth of MSME in Indonesia. Minimal mastery of science and technology are the biggest obstacles for MSME in facing global competition, many MSME owners also do not understand the importance of Information and Communication Technology. Only 20,93\% of MSME have computers to support their business (Scherly, 2019). This study aims to analyze the factors that influence the desire of MSME entrepreneurs to use accounting information systems. The research model was developed using a flow theory approach by analyzing the factors that influence the desire to use an accounting information system, which in turn will have an impact on the actual use of the accounting information system. Also this study combine Theory of Flow and TPB,this is the difference between this study and previous study. 


\section{THEORETICAL FRAMEWORK AND HYPOTHESIS DEVELOPMENT}

\section{Information Systems}

Information systems are the arrangements for people, data, processing, and information technology that interact with each other to collect, process, store, and present the information needed to support the organization (Whitten \& Bentley, 2007; Laudon \& Laudon, 2014; and Stair \& Reynolds, 2016 ). Bodnar and Hopwood (2010) explained that an information system is a collection of resources (people and equipment) designed to convert financial data and other data into information.

There have been many previous studies based on internal factors, such as the sophistication or quality of Information Technology, Organizational characteristics, Business Strategy, Owner's Commitment, and Expert Competence (IT) to support the application of information systems. This shows how important information technology is in implementing an information system.

Several theories were developed to test users' interest in using or adopting information systems, including the Technology Acceptance Model (TAM), the theory of planned behavior (TPB), and the Theory of Flow. In this study, the theory of flow is used as the main theory in explaining the use of accounting information systems. Flow theory states that perceived enjoyment and concentration affect behavioral intention, which in turn has an impact on the actual use of the accounting information system.

In previous social studies, attitudes are a significant factor in determining behavioral intention (Fishbein \& Ajzen 1975; Ajzen 1988). In addition, empirically, attitude is a strong mediator of motivation variables to predict behavioral intention to use information technology.

\section{Theory of Flow}

A concept or theory that is the basis of research in the flow of positive psychology, which views that a good life is characterized by a focus on being fully involved and enjoying every process is called Flow Theory.

Csikszenmihalyi (1990) is the person who first defined the flow of a psychological situation that occurs when a person is in an efficient cognitive condition, gets motivated, and feels happy. A situation where someone will experience a very happy feeling is when they are doing activities that require interaction, one's concentration, and total pleasure during these activities. Focusing on what is done in other ways is also called a part of the flow. When someone experiences the flow, sometimes the individual feels that time passes so quickly while doing a job that feels comfortable so that the individual is able to fully concentrate on completing the work.

Some of the prerequisites for experiencing flow are as follows (Setiadi in Amaliyah, 2016):

\section{a. Goals}

It is a purpose where the goal is able to motivate someone to be able to exert all the skills and efforts they have to achieve these goals. A clear and effective goal can be an effective mobilizer, even when a person is having a lot of difficulty in achieving it.

\section{b. Feedback}

Can come from yourself or others. The best feedback is one that is instantaneous and is immediately captured by the person.

\section{c. High Skill}

the higher the skills an individual has in a field, the more it will open up new possibilities and can increase creativity. 


\section{d. Optimal Challenge}

The optimal challenge is a challenge with a fairly high level of difficulty, but not too easy and not too difficult. Such challenges require individuals to use all their abilities and skills. When facing challenges like these, a new person will realize all the skills he/she has so that emerging skills will emerge.

\section{Research Hypothesis}

\section{The effect of perceived enjoyment to attitude toward to using AIS}

Flow is defined as "the holistic sensation that people feel when they act with total involvement" (Csikszentmihalyi, 1977; Csikszentmihalyi \& Csikszentmihalyi, 1988). When people are in the flow state, they become absorbed in their activities: their awareness is focused on the activity itself; they lose self-consciousness, and they feel they have control over their environment (Csikszentmihalyi, 1977). Thus flow theory, developed in the reference discipline of psychology, has been used to address optimal user experiences with personal computers (Finneran \& Zhang, 2005). Compared with perceived usefulness, which deals with users' extrinsic motivation (Davis, Bagozzi, \& Warshaw, 1992; Venkatesh et al., 2003), flow experience can be seen as an intrinsic motivation. Flow is a complex concept and researchers often measure it through multiple dimensions. Ghani (1995) measured flow using two constructs: enjoyment and concentration.

Activity of using a specific system is perceived to be enjoyable in it's own right, aside from any performance consequences resulting from system use" (Venkatesh, 2000). Perceived enjoyment as an intrinsic motivation has been found to have a significant impact on a user's technology acceptance, especially for hedonic systems (Davis et al., 1992; Koufaris, 2002; Van der Heijden, 2004). When using a technology can bring them fun and pleasure, users will be intrinsically motivated to adopt it. Thus we expect that perceived enjoyment will improve their affective attitude toward using AIS

H1: Perceived Enjoyment positively affects attitude towards using AIS

The effect of attitude toward to using AIS to behavioral intention to use AIS

Attitude is defined as an individual's overall evaluation of performing a behavior. According to TPB, attitude impacts users' behavioral intention.

H2: Attitude towards using AIS positively affects behavioral intention to use AIS

\section{The effect of to behavioral intention to use AIS}

Concentration is another important component of the flow experience. For users to be in a "flow" state, they must first concentrate on their activities (Koufaris, 2002; Novak et al., 2000). If users perform many tasks simultaneously and cannot focus on a limited field, they will not be able to acquire the flow experience.

H3: Concentration positively affects behavioral intention to use AIS.

\section{The effect of behavioral intention to use AIS to actual AIS usage}

According to TPB, attitude impacts users' behavioral intention, which in turn influences their actual behavior. When individuals form positive attitude towards AIS, they will have a stronger intention toward adopting it, thus they are more likely to use it.

H4: Behavioral intention to use AIS positively affects actual AIS usage.

\section{RESEARCH METHODOLOGY}

The research object is the accounting information system, while the unit of analysis in this study is the MSME 
entrepreneurs in Bandung. The population of this research are micro, small and medium entrepreneurs in Bandung City, approximately 140.000 . This research used purposive sampling method that is confined to specific types of people who can provide the desired information, either because they are the only ones who have it, or conform to some criteria set by the researcher (Sekaran, \& Bougie, 2009). sample consists of 100 Micro, Small, and Medium entrepreneurs.

In this study, two types of data were used, they are primary data and secondary data. Primary data collection is done by using a questionnaire method aimed at the observation unit. Furthermore, secondary data is carried out by obtaining information from the Ministry of Cooperatives and MSME.

The purpose of this research is to confirm the theory, so the SEM method used is Covarian Based SEM (CB SEM). When the CB SEM assumptions cannot be fulfilled with distribution normality, minimal sample size, and model complexity, PLS-SEM is a good methodological alternative to theory testing (Hair et al., 2014).In this study, the authors could not meet the sample size because it has limitations in terms of time, cost, and labor, likewise in this study there is a formative measurement model.

\section{RESULTS AND DISCUSSION}

Respondents in this study were the owners of MSME in Bandung. A total of 100 respondents were sampled in this study where $66.0 \%$ were women with the most types of business being in the fashion sector $(52 \%)$, then $21 \%$ in the food and beverage business, and $17 \%$ in the trade sector. The majority of respondents $(56.0 \%)$ have only been in business for 1-3 years, however, there are as many as $40 \%$ of respondents who have been in business for between 4-6 years.

\section{Descriptive Analysis}

In this study, the mean and standard deviation were used to describe the condition of each variable. The mean and standard deviation of the respondent's answer score is useful to provide an overall picture of how Attitude Toward Using SIA, Subjective Norm, Perceived Behavioral Control, Behavioral Intention To Use SIA, and Actual AIS Usage of MSME in Bandung.

Table 1. Descriptive Statistics

\begin{tabular}{ccccccc}
\hline \multirow{2}{*}{ Variable } & Mean & Std. Dev. & Max. & Min. & Mean & Mean \\
& & & & & & \\
\hline PE & 3,68 & 0,42 & 4,33 & 2,33 & 44 & 56 \\
CON & 3,91 & 0,31 & 4,67 & 2 & 83 & 17 \\
ATU & 3,81 & 0,26 & 4,67 & 3,67 & 29 & 71 \\
ITU & 4,18 & 0,27 & 5 & 4 & 37 & 63 \\
AU & 3,59 & 0,42 & 4,67 & 2 & 64 & 36 \\
\hline
\end{tabular}

Measurement of Perceived Enjoyment (PE) uses 3 indicators and based on the answers from 100 respondents obtained an average score of 3.68 (ending with a score of 4), which means that most respondents were satisfied while using the accounting information system. The number of MSME that has a score above the average is less than MSME that has a score below the average.

Concentration (CON) measurement uses 3 indicators and based on the answers from 100 respondents obtained an average score of 3.91 (close to a score of 4), which means that most respondents have concentration when operating the AIS application in their work. The number of MSME that has scores above the average is more than MSME that has scores below the average.

Attitudes towards the use of AIS (ATU) using 3 measurement indicators and based on the results of the answers of 100 respondents obtained. An average score of 3.81 (ending with a score of 4), which means that most respondents like to use accounting information systems. The number of MSME that has scores below the average is more than the MSME that has scores above average.

Measurement of Behavioral intention to use AIS (ITU) uses 3 indicators and based on the results of 100 respondents' 
answers, an average score of 4.18 (close to 4 ) is obtained, which means that most respondents are interested in continuing to use accounting information systems in the future. The number of MSME that has a score above the average is less than that of MSME that has a score below the average.

The measurement of the actual use of AIS (AU) uses 3 indicators and based on the results of 100 respondents' answers, an average score of 3.59 (ending to a score of 4 ) is obtained, which means that most respondents often use accounting information systems. The number of MSME that has scores above the average is more than that of MSME that has scores below the average.

\section{Structural Equation Modelling}

1. Evaluation of the Measurement Model

The measurement model is a model that connects latent variables with manifest variables. From this measurement model, it is known which indicators are more dominant in reflecting latent variables. According to Hair, et al (2014), indicators with factor weights less than 0.4 must be excluded from the measurement model.

In this study, there were 5 latent variables with 15 manifest variables. Perceived satisfaction variables consisted of 3 manifest variables, concentration consisted of 3 manifest variables, attitudes towards using AIS consisted of 3 manifest variables, behavioral intention to use AIS consisted of 3 manifest variables. and the actual use of AIS consists of 3 variable manifests.

Using structural equation modeling with the alternative method of partial least square, a path diagram of the full factor model that affects the use of accounting information systems by MSME is obtained as shown in Figure 1 below:

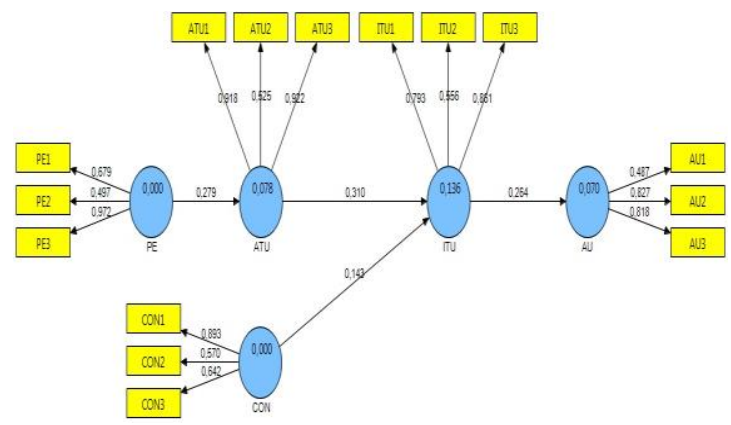

Image 1. Full Model Path Coefficient

In Figure 1, it can be seen that the factor weight on the latent variable perceived enjoyment (PE), the $\mathrm{PE}_{3}$ indicator (running the AIS application in a managed business so far, is a fun thing) is the strongest in reflecting the latent variable perceived enjoyment, on the other hand, the $\mathrm{PE}_{2}$ indicator (studying and operating AIS application in managed businesses so far, is an interesting thing) is the weakest in reflecting the latent variable perceived enjoyment. Furthermore, on the latent concentration (CON) variable, the indicator $\mathrm{CON}_{1}$ (often forgets the time when operating the AIS application on the job) is the strongest in reflecting the latent concentration variable, on the other hand, the $\mathrm{CON}_{2}$ indicator (often paying less attention to surrounding events when operating the AIS application on the job) is the weakest in reflecting the latent concentration variable.

Attitude toward using AIS (ATU) latent variable, the $\mathrm{ATU}_{3}$ indicator (a wise decision to use the AIS application in a managed business) is the strongest in reflecting the latent variable attitude toward using SIA, whereas the $\mathrm{ATU}_{2}$ indicator (feeling happy using the AIS application in a managed business) is the most powerful. They are weak in reflecting on the latent variable attitude toward using SIA. Then on the latent behavioral variable intention to use AIS (ITU), the ITU $\mathrm{IT}_{3}$ indicator (wishing to continue to use the AIS application in the future) is the strongest in reflecting the latent behavioral variable intention to use SIA, on the other hand, the ITU ${ }_{2}$ indicator (recommending the importance of using 
the AIS application to others ) is the weakest in reflecting on latent behavioral variables intention to use SIA.

Finally, on the actual latent variable AIS usage $(A U)$, the $\mathrm{AU}_{2}$ indicator (the average time spent each week in operating the AIS application) is the strongest in reflecting the actual latent variable AIS usage, on the other hand, the $A U_{1}$ indicator (frequency of using AIS applications in a week) is the weakest in reflecting on latent variables actual AIS usage. Furthermore, to find out whether the indicators used to measure the five latent variables have a high degree of conformity, the composite reliability and variance extracted are calculated. Following are the results of the calculation of composite reliability and variance extracted for each latent variable indicator.

Table 2. Composite Reliability (CR) and Average Variance Extracted (AVE) of Each Latent Variable

\begin{tabular}{ccc}
\hline Latent Variable & CR & AVE \\
\hline PE & 0,774 & 0,551 \\
CON & 0,751 & 0,511 \\
ATU & 0,844 & 0,656 \\
ITU & 0,787 & 0,560 \\
AU & 0,774 & 0,530 \\
\hline
\end{tabular}

According to Hair, et al $(2014 ; 102)$ if the $\mathrm{CR}$ value ranges from 0.70 to 0.90 it is considered satisfactory. In the latent variable perceived enjoyment, the extracted variance value is 0.551 which indicates that $55.1 \%$ of the information contained in each indicator can be represented through the perceived enjoyment variable. The composite reliability value of the latent variable perceived enjoyment is 0.774 which is still greater than the recommended value, like 0.70 .

For the latent concentration variable, the variance extracted value is 0.511 indicating that on average $51.1 \%$ of the information contained in each indicator can be represented through the latent concentration variable. The composite reliability value for the latent concentration variable is 0.751 , which is still greater than the recommended value, namely 0.70 .

In the attitude toward using AIS latent variables, the variance extracted value is 0.656 , indicating that on average $65.6 \%$ of the information contained in each indicator can be represented by the attitude toward using AIS latent variables. The composite reliability value for the latent variable attitude toward using AIS $(0.844)$ is still greater than the recommended value, namely 0.70 .

In the latent behavioral variable intention to use SIA, the value of the variance extracted is 0.560 which indicates that on average $56.0 \%$ of the information contained in each indicator can be represented through the latent variable behavioral intention to use SIA. Then the composite reliability value for the latent variable perceived usefulness $(0.787)$ is still greater than the recommended value, such as 0.70 .

For the actual latent variable AIS usage, the variance extracted value was 0.530 , indicating that on average $53.0 \%$ of the information contained in each indicator could be represented through the actual AIS usage latent variable. Then the composite reliability value of the latent variable actual AIS usage $(0.774)$ is still greater than the recommended value, namely 0.70 .

\section{Structural Model Evaluation}

The structural model looks at the effect of the exogenous latent variable on the endogenous latent variable. Based on the results of data processing obtained as follows:

\section{Table 3. Structural models of factors that influence the use of accounting information systems by MSME}

Endog Exogenous Composites R 


\begin{tabular}{lccccc}
\hline $\begin{array}{l}\text { enous } \\
\text { Compo } \\
\text { sites }\end{array}$ & PE & CON & ATU & ITU & $\begin{array}{l}\text { squa } \\
\text { re }\end{array}$ \\
\hline ATU & 0,279 & - & - & - & 0,078 \\
& $(2,185)$ & & & & \\
\hline ITU & - & 0,143 & 0,310 & - & 0,136 \\
\multicolumn{7}{c}{$(2,107)$} & $(1,764)$ & & \\
\hline AU & - & - & - & 0,264 & 0,070 \\
& \multicolumn{5}{c}{$(2,704)$} \\
\hline \multicolumn{7}{l}{ Note: The number in parentheses is the t-stat value. }
\end{tabular}

Based on the R-square value, it can be seen that the perceived enjoyment has an effect of $7.8 \%$ on attitude toward using SIA. Then the concentration and attitude toward using AIS has an effect of $13.6 \%$ on behavioral intention to use SIA. And behavioral intention to use AIS has an effect of $7.0 \%$ on actual AIS usage.

From table 3 , it can be seen that $t_{\text {statistic }}$ perceived enjoyment towards attitude toward using AIS is 2.185 and greater than $t_{\text {critic }}(1.64)$, so at an error level of $5 \%$, it was decided to reject $\mathrm{Ho}$ and accept $\mathrm{Ha}$. So it can be concluded that perceived enjoyment has a positive effect on attitude toward using AIS on MSMEs in Bandung. Perceived enjoyment as an intrinsic motivation has been found to have a significant impact on a user's technology acceptance, especially for hedonic systems (Davis et al., 1992; Koufaris, 2002; Van der Heijden, 2004). When using a technology can bring them fun and pleasure, users will be intrinsically motivated to adopt it. Perceived enjoyment as an intrinsic motivation has been found to have a significant impact on a user's technology acceptance, especially for hedonic systems (Davis et al., 1992; Koufaris, 2002; Van der Heijden, 2004). When using a technology can bring them fun and pleasure, users will be intrinsically motivated to adopt it and perceived enjoyment will improve their affective attitude toward using AIS.

The $t_{\text {statistic }}$ value of the attitude toward using AIS variable towards behavioral intention to use AIS which can be seen in table 3 is 1.764 and is greater than $t_{\text {critic }}(1.64)$, so at a $5 \%$ error level, it was decided to reject $\mathrm{Ho}$ so that $\mathrm{Ha}$ was accepted. It can be concluded that the attitude toward using AIS has a positive effect on behavioral intention to use AIS on MSME in Bandung. Attitude is defined as an individual's overall evaluation of performing a behavior. According to TPB, attitude impacts users' behavioral intention.

The $t_{\text {statistic }}$ value for the attitude toward using AIS variable on behavioral intention to use AIS which can be seen in table 3 is 1.764 and this value is greater than $t_{\text {critic }}(1.64)$. Since the $t_{\text {statistic }}$ value is greater than $t_{\text {critic }}$ value, at an error level of $5 \%$ it was decided to reject $\mathrm{Ho}$ so that $\mathrm{Ha}$ was accepted. So based on the test results, it can be concluded that the attitude toward using AIS positively affects the behavioral intention to use AIS for MSME in Bandung. Concentration is another important component of the flow experience. For users to be in a "flow" state, they must first concentrate on their activities (Koufaris, 2002; Novak et al., 2000). If users perform many tasks simultaneously and cannot focus on a limited field, they will not be able to acquire the flow experience.

In table 3, it can be seen that the $t_{\text {statistic }}$ value of the behavioral intention to use AIS on actual AIS usage (2.704) is greater than $t_{\text {critic }}(1.64)$, so at a $5 \%$ error level, it can be concluded that $\mathrm{Ha}$ is accepted, namely positive behavioral intention to use AIS affect the actual AIS usage in UMKM in Bandung city. According to TPB, attitude impacts users' behavioral intention, which in turn influences their actual behavior. When individuals form positive attitude towards AIS, they will have a stronger intention toward adopting it, thus they are more likely to use it.

\section{CONCLUSION}

From the results of the research and discussion, it can be concluded that Perceived enjoyment has a positive effect on attitude toward using AIS on MSME in Bandung, the attitude towards the use of AIS positively affects the behavioral intention of using AIS in MSME in Bandung, concentration positively on behavioral intention to use AIS in MSME 
in Bandung, and Behavioral intention to use AIS positively affects the actual AIS usage of MSME in Bandung

\section{REFERENCES}

Ajzen, I. (1988). Attitudes, Personality, and Behavior. Chicago: Dorsey Press.

Bodnar, G., \& Hopwood, W. (2010). Accounting Informartion Systems 10th edition. United States of America: Pearson Education Inc.

Hair, Jr, J., G Thomas, M., M.Ringle, C., \& Sarstedt, M. (2014). A Primer on Partial Least Squares Structural Equation Modeeling (PLS-SEM). California USA: SAGE Publications Inc.

Hartono, J. (2007). Model Kesuksesan Sistem Teknologi Informasi. Yogyakarta-Indonesia: Andi.

Laudon, K., \& Laudon, J. (2014). Sistem Informasi Manajemen: Mengelola Perusahaan Digital Edisi 13. Jakarta: Salemba Empat.

Stair, R., \& Reynolds, G. (2016). Fundamentals of Information Systems 8 th Edition. BostonUnited States of America: Cengage Learning.

Sudaryanto , \& Hanim, A. (2002). Evaluasi Kesiapan UMKM Menyongsong Pasar Bebas Asean
(AFTA) : Analisis Perspektif dan Tinjauan Teoritis. Jurnal Ekonomi Akuntansi Manajemen, Vol 1 No 2 Desember 2002.

Whitten, J., \& Bentley, L. (2007). System Analysis \& Design Methods Seventh Edition. New York, USA: McGraw-Hill. 